His zoological researches commenced with a series of papers on Hydrozoa but soon extended to other marine invertebrates, land and water vertebrates and archæology. One of his interesting economic suggestions, a method of keeping the submarine shafts of an electricity station free from blocking by the invasion of mussels, has been in successful operation since 1927. It is not possible in a brief note to do justice to his remarkable energy and enthusiasm nor to the wide range of his knowledge and interests. His services were recognized by the conferment of a C.B.E. in 1948 and an honorary LL.D. by Aberdeen this year. His skill in drawing is reflected in all his work, and outside scientific circles has been recognized by the Royal Scottish Academy, which has exhibited a number of his delightful water colours. A most approachable man, he has always been ready to share his knowledge and to encourage the humblest of inquirers. Many have enjoyed his loyal friendship and some perhaps a round of golf with him.

Dr. M. M. Swann

Dr. Mrchael Meredith Swank has been appointed to succeed Prof. Ritchie. Educated at Winchester and Cambridge, Swann, after graduating in 1940 with a first-class in zoology, joined the Intelligence Corps, served in Iceland as a captain instructor in arctic warfare, benefiting by his earlier experience with the Cambridge Iceland Expedition of 1939, and was thereafter engaged in operational research in Great Britain and Normandy. When, as lieut.-colonel in the Scientific Adviser's Branch of the War Office, he was demobilized in 1946, he returned to the Zoology Department at Cambridge as temporary demonstrator, with a research fellowship at Gonville and Caius College. He has been a University demonstrator since 1948. Dr. Swann has devoted himself actively to the investigation of the cell, and his studies have followed three main lines- the refinements of mitosis, the fertilization reactions of sea-urchin eggs, and the mechanical properties of cell-membranes. In the first, his Ph.D. thesis (1950) was on "Structural Factors in Mitosis", and with J. M. Mitchison he has elaborated the use of polarized light in the study of cell changes affecting membranes, mitosis and cleavage. In the second, in collaboration with Lord Rothschild, he has elucidated the responses of the sea-urchin egg to contact with spermatozoa, and in the last he, along with Mitchison, has attempted to link the processes of cell-cleavage with the physical properties of the cell-membrane. At the age of thirty-two years Dr. Swann is not the most youthful of Edinburgh's long succession of professors of natural history, but to better his record one must go back to 1804 and the appointment at the age of thirty of Robert Jameson, the teacher of Charles Darwin, Edward Forbes, Sir William Jardine, William Scoresby, John Goodsir and many other well-known naturalists.

\section{Research at Edinburgh on Cancer}

From the estate of the late George Fisher Melville, advocate, of Edinburgh, the sum of $£ 270,000$ has now become available for the encouragement of activities relating to "the care and cure of cancer". Some time ago, Messrs. Tod, Murray and Jamieson, W. S., of Edinburgh, in whose hands the affairs of the estate rest, sought the advice of representatives of the Royal Colleges of Medicine and of Surgery of Edinburgh and of the University, and with the help of this ad hoc committee so formed drew up a scheme for the appropriate utilization of this money. 'T'his scheme has now gained the approval of the Court of Session. The next step will be the formal approach by the trustees to the Royal Colleges and to the University of Edinburgh requesting that each of these bodies shall nominate a trustee and three members of a permanent scientific advisory committee which will at once proceed to formulate recommendations for carrying the scheme into practical effect. Since the care of the patient is now a responsibility of the State, it is certain that the scientific advisory committee will be mainly, if not exclusively, concerned with the encouragement of research into the nature and causes of malignancy, and thus into the ways in which it may be prevented, treated and controlled. The hands of the trustees are not tied. They are empowered to nourish researches being undertaken in hospitals and elsewhere, to build and equip new laboratories, to institute research fellowships and to amalgamate or to form alliances with other bodies actively interested in the same general field of inquiry. In these days, opportunity of this magnitude knocks but very rarely upon the doors of Scottish academic institutions. The responsibility to be assumed by the scientific advisory committee is, therefore, exceedingly heavy. To exploit this opportunity to the best advantage to all concerned-to those who suffer and to those who seek knowledge that may give power to abolish suffering-will demand the exercise of much wisdom. Of this there is in Edinburgh a rich store.

\section{Popular Interests in Science}

AN investigation into the interests of about 391 people (241 males, 150 females) who are taking science subjects in adult education classes showed that the females were more extreme in their preferences and dislikes than the males (Health Educ. $J ., 9$, No. 4). Males were most interested in studying future advances and new discoveries and theories in science and, next to these, medicine, health and the industrial applications of science. Medicine and health were the most popular subjects for females, and almost as popular were pure biology and psychology. Neither males nor females took much interest in aeronautics or in the public direction and use of science; even less interest was shown in the work of scientific institutions and the results of science surveys and commissions. This may indicate that the 'ordinary' man is not fully conscious of the impacts of science on communal life or, perhaps, is little interested in the development of society as distinct from the individual. Confirmation of this investigation was obtained from a group of men in an Army education college. Although the men were not necessarily interested in science, their likes and dislikes were very similar to those of the younger men in the original group.

\section{T. R. Wilson and the Cloud Chamber}

THw fourth in the series of attractively illustrated monographs dealing with the association of prominent men of science with the Cambridge Instrument Co., Itd., is entitled "C. T. 1R. Wilson and the Cloud Chamber" (pp. iv +16 ; from 13 Grosvenor Place, London, S.W.1; 1952 ; free) and is written by S. Barron, with a foreword by Sir Lawrence Bragg. Reference is made, both in the foreword and in the text, to Wilson's skill and patience in building apparatus and to the remarkable success of the first complete cloud chamber constructed by Wilson in 